\title{
JPEB
}

Jurnal Penelitian Ekonomi dan Bisnis, 5 (2), 2020, Hal: 180-193

http://www.jpeb.dinus.ac.id

\section{BRAND IMAGE AS A MEDIATION OF ELECTRONIC WORD OF MOUTH ON PURCHASING INTENTION OF LANEIGE}

\author{
Chikita Fatimasokasari Supradita ${ }^{*}$, Surpiko Hapsoro Darpito ${ }^{2}$ dan Dwi Hari Laksana ${ }^{3}$ \\ ${ }^{1,2,3}$ Departement of Management, Faculty of Economics and Business, Pembangunan \\ Nasional "Veteran" University Yogyakarta \\ SWK 104 Street, Condongcatur, Depok, Sleman, DI Yogyakarta, Indonesia \\ *Corresponding Author: chikitass97@gmail.com
}

Received: February 2020; Revised: July 2020; Published: September 2020

\begin{abstract}
The purpose of the study was to know and analyze the role of brand image as a mediator of the impact of the Electronic Word of Mouth on purchasing intention of Laneige's product. A sample of 100 respondents used a purposive sampling technique. The type of test used to analyze the data was the validity and reliability test. The data analysis technique used is path analysis. The results of the Electronic Word of Mouth study have a significant and positive effect on brand image and purchasing intention. The Brand image also has a significant and positive impact on purchasing intention and directly has a role as a mediator on the impact of Electronic Word of Mouth on purchasing intention of Laneige's Product.
\end{abstract}

Keywords: Electronic Word of Mouth; Brand Image; Purchasing Intention 


\section{INTRODUCTION}

As the development of information and communication technology is increasingly qualified, Korean Wave (K-Wave) or known as Hallyu, began to enter various countries around the world (Kuwara, 2014). The Korean wave is a term given to the spread of the Korean wave globally in various countries, including Indonesia, judging from the above understanding, the Korean Wave can be categorized as a phenomenon. Some of them even made K-Wave or Hallyu the center of fashion and beauty, which was considered as a trend.

Korean trend or Hallyu adorns digital media so much that Korean things are attractive for consumption. One of them has clean and flawless skin like artists in South Korea become everyone's dream. That is the reason why beauty or skincare products from South Korea are booming among teenagers and adults. Therefore, in this decade, Korean beauty (K-beauty) has taken over the global beauty industry with a wide variety of products, attractive packaging, and natural product composition.

Starting from Korean Pop (K-Pop) to the present K-beauty, Korea has mastered global appeal. By targeting the millennium segment, which is currently pleased with something compelling, comfortable, and practical, K-beauty is ready to launch various skincare variants that are considered suitable for Asian skin, including Indonesia. Research on beauty products being done on new products in South Korea than in other countries because there are so many competing brands, and they are trying to be the best.

However, this year the media discussed Japanese beauty (J-beauty), which was back to compete with K-beauty products. The media said that J-beauty has returned to overcome the current "trend" buzzy. In this case, Amorepacific Corporation, which is a beauty and cosmetic company in South Korea, suffered a loss of up to $76 \%$ in the fourth quarter of 2017 due to a decrease in product sales. In this case, beauty and cosmetic companies in South Korea experienced much decline in purchasing intention. Tight purchasing intention competition causes companies to have to think about a suitable strategy in dealing with competition.

The existence of intense sales competition causes companies to think about the right strategy in the face of competition. This competition consists of several forms, such as price cuts, variety and quality, packaging, design, market segmentation, and advertising/promotion (Marbun, 2003). This opinion is justified by Martins (2018), who said that the sales promotion of a product could increase consumer purchasing intention.

In line with the development of existing technology, marketing has now been done with internet technology or so-called digital marketing. Digital marketing is assisted by digital influencers as third parties to provide a review of a product online. Prospective customers can look for reviews on several platforms on social media online before buying a product. Online consumer review (OCR) or can be referred to as Electronic Word of Mouth, is one feature that has attracted much attention from academics and the public as one of the most influential factors in determining consumer purchasing interest (Hu et al., 2006).

Social media can also be used as an early-warning system or monitor trends in the market (Stelzner, 2016). Stelzner (2016) also conducted a survey that showed that $90 \%$ of marketers agreed that social media was an essential part of their business, and $68 \%$ of marketing analyzed the social media activities of their business. The survey is reinforced by the opinion of e-marketers, who explain that $61 \%$ of consumers are affected by blog reviews and sharing reviews on various social media platforms (Hatane \& Liana, 2004). 
Laneige products are one of Korea's skincare and cosmetic brands that intentionally or unintentionally carry out digital marketing through Electronic Word of Mouth on social media such as Youtube, Twitter, Femaledialy, and other platforms. The existence of reviews or reviews given by other consumers, for example in a sharing review on a platform or community, can influence other potential consumers on their purchasing intention (Jalilvand $\&$ Samiei, 2012) for example the reviews from consumers of cosmetics products "Laneige" on social media (Youtube, Twitter, Femaledialy, Instagram and other platforms).

In addition to "Laneige" cosmetic products, other cosmetic products that are widely given reviews on social media as a form of Electronic Word of Mouth are cosmetics products "Some by Mi." "Some by Mi" cosmetics attracts a lot of consumers' attention because of positive comments on social media that make the brand image of a product positive so that consumers' purchasing intention increases.

Jalilvand and Samiei (2012) argue that Electronic Word of Mouth is one of the practical factors that influence brand image and purchasing intention in the consumer market. This opinion was also proven by Semuel and Lianto (2014), which stated that Electronic Word of Mouth had a positive effect on brand image, brand trust, and purchasing intention. However, a different opinion was expressed by Reza M and Retno (2018), who said that Electronic Word of Mouth had no positive and significant influence on purchasing intention either through or not through brand image. However, Electronic Word of Mouth will have a positive and significant effect on purchasing intention if through brand trust as its medium.

Based on this background, the following problem formulations can be obtained: 1) Is there any influence between Electronic Word of Mouth and brand image on Laneige products? 2) Is there any influence between Electronic Word of Mouth on purchasing intention in Laneige products? 3) Is there any influence between brand image and purchasing intention in Laneige products?

\section{LITERATURE REVIEW \\ Electronic Word of Mouth}

Electronic Word of Mouth is a form of marketing communication that contains positive or negative statements made by potential customers, customers, or former customers or companies, which are willing for many people or institutions through the internet (HennigThurau et al., 2004). Goldsmith (2008) defines Electronic Word of Mouth as any internet-based communication about the use or characteristics of a product. The expansion of the internet has given more access to consumer comments posted on the internet and allows consumers to offer advice regarding their consumption by involving Electronic Word of Mouth. The dimension of Electronic Word of Mouth: Intensity (frequency of accessing information from social media, frequency of interaction with social media users, and the reviews written by social media users), Valence of Opinion (positive or negative comments from social network users and recommendations from social networks), Content (information about variations of a product, information about leather, and information about prices offered).

Factors of Electronic Word of Mouth are platform assistance, venting negative feelings, concern for other consumers, extraversion or positive self-enhancement, social benefit, economic incentives, helping the company, advice seeking. Schiffman and Kanuk (2008) said, indicators of consumer's purchasing intention 1) An interest in seeking more information about 
products consumers are aroused by the need to be driven to looking for more information , 2) consider buying, through information gathering, consumers learn about competing brands and heir strengths, 3) The desire to know the product, consumers have a desire to know products because they view the product has different abilities in providing benefits that are used to utilize wholeness, 4) interest in trying products, after the consumer has fulfilled the needs, studying the competing brands and the strengths of these brands, consumers will look for certain benefits from solutions and will evaluate these products, 5) the desire to have a product, consumers will pay great attention to attributes that provide the benefits they are looking for so that they will take stand (decisions preferences) towards the product through the evaluation of attributes and form an intention to buy or have a preferred product.

\section{Purchasing Intention}

Purchasing intention is a model of a person's preferences towards products, which is very suitable in measuring attitudes toward a specific class of products, services, or brands (Schiffman and Kanuk, 2008). Purchasing intention shows the possibility that consumers will plan or want to buy certain products or services in the future (Wu et al., 2011). According to Venkatesh and Davis (2000), purchasing intention is proven to be a valid predictor of actual behavior with the indicator of interest looking for more information about the product, considering buying, the desire to know the product of interest to try the product, the desire to have a product. Several factors that influence purchasing intention 1) Stimulation, is a condition intended to encourage or cause someone to act. 2) Awareness is something that enters the product, and service itself influences a person's thinking. 3) Search for information, can be divided into private information, sourced from consumers' memories to choose goods or services that satisfy them, external information, information originating from advertisements, through friends, or from mass media, ensuring the unique nature of each choice, at this stage the consumer collects information related to the characteristics of each choice, alternative selection, after information relating to the desired product has been obtained.

The consumer collecting information, namely: the nature of the product (color, size, and packaging) for example if a consumer buys clothes, then he will pay attention to materials, models, colors, and prices, the important factor of the product depends on the characteristics of products that are memorable and enter the minds of consumers, trust in the brand, is a tool that used by consumers to distinguish each brand with their respective characteristics. This trust is the result of the experience and perception of consumers, the function of product which consumers who expect satisfaction with the desired product, the product valuation process can be done by using specific assessment procedures to choose from the many alternatives. Place of purchasing is one of the considerations in stores where consumers will buy products or services. Finally, purchasing is the last stage where the consumer has made a choice and is ready to exchange money for the goods/services. Two factors also determine the consumer's decision, namely the attitude of others and unexpected situational factors.

\section{Brand Image}

Brand image is the way people think about a brand abstractly in their thinking, even when they think about it, they do not deal directly with the product (Kotler and Keller, 2012). A good brand image, to some extent, shapes how we decide to buy products or services from 
certain brands ( $\mathrm{He}$ and $\mathrm{Li}, 2012)$. Underlining that brand image is seen by consumers' perceptions and beliefs that reflect relationships in consumers' memories (Afriani et al., 2019). With indicators: consumer perception of product introduction, consumer perception of product quality, consumer perception of size, consumer perception of durability, consumer perception of product color, consumer perception of price, consumer perception of location.

According to Shimp (2003: 592), there are three parts contained in measuring brand image, namely: 1) Attributes are the characteristics or various aspects of the brand being advertised. Attributes are divided into two things that are not related to the product (example: price, packaging, usage and image usage), and things related to the product (example: color, size, design). 2) Benefits, divided into three parts: Functional, i.e., benefits that seek to provide solutions to consumption problems or potential problems that can be experienced by consumers, symbolic, which is directed at the desires of consumers to improve themselves, valued as members of a group, affiliation, and a sense of belonging, experience, which is the consumer is a representation of their desire for products that can provide a sense of pleasure, diversity, and cognitive stimulation. 3) Overall Evaluation, is a subjective value or importance which the customer adds to the consumption result.

Brand image has benefits for the company, as stated in Rangkuti (2004: 17): 1) Brand image is made as a goal in the company's strategy. 2) Brand image can be used as a basis for competing with other brands of similar products. 3) Brand image can also help renew sales of a product. 4) Brand image can be used to evaluate the quality effects of marketing strategies. 5) Brand image can be generated from other factors outside the company's strategic efforts.

According to Kotler and Keller (2012: 261) some indicators influence brand image, namely: 1) Consumer perception of product introduction, 2) Consumer perception of product quality, 3) Consumer perception of size, 4) Consumer perception of endurance, 5 ) Consumer perception of the color of the product, 6) Consumer perception of prices, 7) Consumer perception of the location. The dimension of brand image (Keller, 2013): 1) Brand Identity is a physical identity associated with a brand or product so that it is easy to consider and adapt to other brands or products, such as logos, colors, packaging, location, corporate identity, slogans and other, 2) Brand Personality is a typical character a brand that forms a certain personality, makes it easy for customers to distinguish from other brands in the same category, 3) Brand Asociation is always specific meeting a brand, as a unique product offering. Examples include sponsorship or social responsibility activities, very strong issues, certain symbols, and meanings attached to brands, 4) Brand Attitude and Behavior are attitude or special offers and added value offered. Attitudes and behavior, activities and attributes attached to the brand when dealing with customers, including employee relations and brand owners, 5) Brand Benefit and Competence are values and the advantages offered by a brand for customers who make customers can feel the benefits, desires, dreams, and obsessions manifested by what is offered.

Factors of Brand Image (Schiffman and Kanuk, 2008): 1) Quality related to the quality of the product goods or services offered by producers with certain brands can be trusted or relied on, related to opinion or agreements formed by the public about a product consumed, 2) Service, relating to the duties of producers in serving, 3) Risk, related to the magnitude of the consequences or benefits and losses that may be experienced consumption, 4) Price, related to the high or low the amount of money spent by consumers affect a product, also affects the longterm image. 


\section{Electronic Word of Mouth and Brand Image}

Semuel and Liana (2004) state that Electronic Word of Mouth has a significant effect on brand image. Electronic Word of Mouth as one of the marketing tools in order to convince consumers and immediately be clear and understand about a product. Previous research was also conducted by Jalilvand and Samiei (2012), state that Electronic Word of Mouth was one of the most effective factors to influence the brand image. Kala and Chaubey (2018) state that there was a significant and positive influence of Electronic Word of Mouth and brand image so that the emphasis on Electronic Word of Mouth would maximize brand image. In 2019, Arif conducted a study on Citilink customers with results that support previous studies that Electronic Word of Mouth significantly and positively influences brand image. Electronic Word of Mouth can create a brand image for a company and build trust among buyers (Rahman, 2020)

$\mathrm{H}_{1}$ : Electronic Word of Mouth has a significant positive effect on Brand Image

\section{Electronic Word of Mouth and Purchasing Intention}

Research conducted by Jalilvand and Samiei (2012) on the observation of virtual communities on Facebook as a place for consumers to share experiences about the products and services provided. The result is Jalilvand and Samiei (2012) say that positive electronic word of mouth has a vital function to increase purchasing intention by creating an image that benefits the company and the brand itself. Litvin et al. (2008) research results show that Electronic Word of Mouth based on facts and quantity about products can have a positive impact on purchasing intention. According to Alharbi et al. (2019), Electronic Word of Mouth has a vital role in helping companies understand consumer's demands and purchasing intention in their various products because Electronic Word of Mouth has a significant and positive influence on purchasing intention.

$\mathrm{H}_{2}$ : Electronic Word of Mouth has a significant positive effect on Purchasing Intention

\section{Brand Image and Purchasing Intention}

According to Jalilvand and Samiei (2012), there is a positive influence of brand image on purchasing intention. Empirical evidence indicates that Brand Equity influences consumer purchasing intention in a variety of contexts (Chang \& Liu, 2009). Wang and Yang (2010: 177) say that the influence of brand credibility on purchasing intention makes brand awareness and brand image a moderating variable, with the results of the brand image having a positive effect on purchasing intention. However, a different opinion was expressed by Reza M and Retno (2018), who stated that brand image had no positive and significant effect on product purchasing intention.

$\mathrm{H}_{3}$ : Brand Image has a significant positive effect on Purchasing Intention

\section{Electronic Word of Mouth and Purchasing Intention on Brand Image}

Jalilvand and Samiei (2012) state that brand image has a direct influence on purchasing intention and also the indirect effect of Electronic Word of Mouth on purchasing intention itself. Wang and Yang (2010: 177) state that the influence of brand credibility on purchasing intention makes brand awareness and brand image a moderating variable, with the results of 
the brand image having a positive effect on purchasing intention. An empirical study was also conducted by Samuel and Lianto (2014: 53), which showed that there was a significant relationship between Electronic Word of Mouth and purchasing intention. However, a different opinion was expressed by Reza M and Retno (2018), who stated that Electronic Word of Mouth had no positive and significant effect on purchasing intention through brand image.

$\mathrm{H}_{4}$ : Electronic Word of Mouth has a significant positive effect on Purchasing Intention with Brand Image as an intervening variable

\section{RESEARCH METHODS}

This research was conducted in Sleman Regency. The population used is the entire community in Sleman Regency, who have an interest in buying Laniege products through social media (Youtube, Twitter, Femaledaily, and other platforms). The sample of this research is some people in Sleman Regency who have an interest in buying Laniege products after accessing social media (Youtube, Twitter, Femaledialy, and other platforms). In determining the sample size in this study is based on several statisticians who suggest that if the population number unknown, then the sample size used in this study is at least 100 respondents (Sigit, 1999). The sampling technique uses a purposive sampling technique, namely the determination of respondents from specific criteria. Respondent criteria included 100 respondents who were part of the community in Sleman Regency who knew and had an interest in buying Laniege products because they accessed social media (Youtube, Twitter, Femaledialy, and other platforms).

The study discusses the influence of brand image as a mediation of Electronic Word of Mouth on purchasing intention in "Laneige" products relating to concepts or theories into marketing. This research starts with a theory and a hypothesis, which then raises a problem or assumption. Therefore, the approach used in research is quantitative. The data used are primary data obtained through questionnaires distributed by researchers. The data analysis technique used in this study is path analysis. Path analysis aims to identify the pathway that causes a particular variable to other variables that influence it (Sarwono, 2012). The t-test shows how far the influence of one independent variable individually / partially in explaining the variation of the dependent variable (Ghozali, 2018). The results of the t-test SPSS output can be seen in the coefficients table in the Sig. (significance). In the table, it can be explained that: if the significant value of $t \leq 0.05$, it can be said that the independent variable has a partial effect on the dependent variable, if the significant value of $t>0.05$, it can be said that the independent variable partially does not affect the dependent variable.

Intervening hypothesis testing on path analysis can be done using the Sobel test. The Sobel test was conducted to determine the effect of intervening variables, namely, brand image. The Sobel test is done by testing the strength of the indirect effect of independent variables on the dependent variable through intervening variables (mediation). 


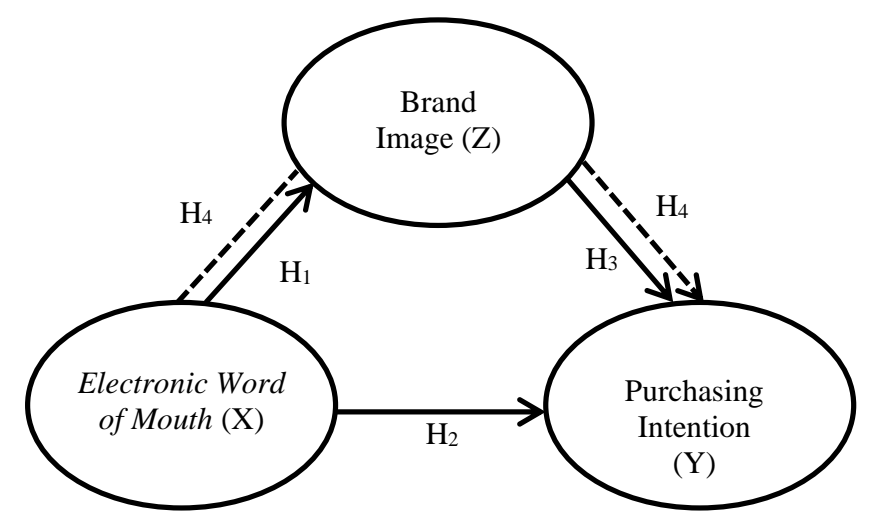

Figure 1. Path Analysis Conseptual

Source: Jalilvand \& Samiei, 2012

\section{RESULT AND DISCUSSION}

\section{Respondent Description and Analysis}

Characteristics of respondents in this study are presented in the following table:

Table 1. Respondent Characteristics

\begin{tabular}{llrr}
\hline Characteristics & Inf & Total & Percentage \\
\hline \multirow{5}{*}{ Age } & $<20$ years & 12 & $12 \%$ \\
& 20 years & 21 & $21 \%$ \\
& 21 years & 50 & $50 \%$ \\
Total & 22 years & 13 & $13 \%$ \\
& $\geq 23$ years & 4 & $4 \%$ \\
\multirow{3}{*}{ Profession } & Students & 100 & $100 \%$ \\
& Employee & 86 & $86 \%$ \\
Total & Entrepreneur & 6 & $6 \%$ \\
& Other & 5 & $5 \%$ \\
Income & & 3 & $3 \%$ \\
& $>$ Rp. 1.5 million & 100 & $100 \%$ \\
Total & $>$ Rp. 1.5 million - Rp. 3 million & 73 & $73 \%$ \\
& $>$ Rp. 3 million - Rp. 4.5 million & 21 & $21 \%$ \\
& $>$ Rp. 4.500.001 & 2 & $2 \%$ \\
& & 4 & $4 \%$ \\
& & 100 & $100 \%$ \\
\hline
\end{tabular}

Based on table 1, it can be seen that the majority of respondents are 21 years old namely as many as 50 people (50\%), respondents aged less than 20 years are 12 people (12\%), 22 years old are 13 people (13\%), and ages are over 234 years (4\%).

The majority of respondents were known to be 86 students (86\%). Other respondents who have jobs as Employees are six people (6\%), Entrepreneurs are five people (5\%), and other jobs are three people (3\%). 
The majority of respondents' income is less than Rp. 1,500,000 as many as 73 people (73\%). Other respondents who have an income of between Rp. 1,500,001 - Rp. 3,000,000 as many as 21 people (21\%), between Rp. 3,000,001 - Rp. 4,500,000 as many as two people (2\%), and respondents who have an income of more than Rp. 4,500,001 as many as 4 people (4\%).

\section{Validity and Reliability Test Results}

The validity test aims to measure the validity instrument is used to obtain data in a study. The minimum requirement for a valid instrument is its validity index value of $\geq 0.3$. In this study, what will be tested is the validity of the Electronic Word of Mouth variable as an instrument variable $\mathrm{X}$ and Purchasing Intention as an instrument variable $\mathrm{Y}$ and Brand Image as an instrument variable $\mathrm{Z}$. Based on Table 2, it can be seen that all statements have a correlation coefficient with $t_{\text {value }}>t_{\text {table }}$.

Table 2. Validity Test Results

\begin{tabular}{crrrr}
\hline Item & $\begin{array}{r}\mathbf{R} \\
\text { value }\end{array}$ & $\begin{array}{r}\mathbf{R} \\
\text { table }\end{array}$ & Sig. & Inf. \\
\hline X.1 & 0,717 & 0,361 & 0,000 & Valid \\
X.2 & 0,634 & 0,361 & 0,000 & Valid \\
X.3 & 0,819 & 0,361 & 0,000 & Valid \\
X.4 & 0,752 & 0,361 & 0,000 & Valid \\
X.5 & 0,886 & 0,361 & 0,000 & Valid \\
X.6 & 0,595 & 0,361 & 0,001 & Valid \\
X.7 & 0,710 & 0,361 & 0,000 & Valid \\
X.8 & 0,665 & 0,361 & 0,000 & Valid \\
Y.1 & 0,859 & 0,361 & 0,000 & Valid \\
Y.2 & 0,931 & 0,361 & 0,000 & Valid \\
Y.3 & 0,802 & 0,361 & 0,000 & Valid \\
Y.4 & 0,825 & 0,361 & 0,000 & Valid \\
Y.5 & 0,873 & 0,361 & 0,000 & Valid \\
Z.1 & 0,587 & 0,361 & 0,000 & Valid \\
Z.2 & 0,787 & 0,361 & 0,000 & Valid \\
Z.3 & 0,687 & 0,361 & 0,000 & Valid \\
Z.4 & 0,740 & 0,361 & 0,000 & Valid \\
Z.5 & 0,603 & 0,361 & 0,000 & Valid \\
Z.6 & 0,494 & 0,361 & 0,006 & Valid \\
Z.7 & 0,723 & 0,361 & 0,000 & Valid \\
\hline
\end{tabular}

Source: Processed Primary Data, 2019

The reliability test is done to check whether the instrument used is reliable or not. The purpose of reliable is if the instrument is tested repeatedly, then the results will be the same. Reliability testing with Cronbach's Alpha can be seen from the Alpha value; if Alpha $>r_{\text {table }}$ is 0.6, then it can be said to be reliable. Reliability testing with Cronbach's Alpha can be seen from the Alpha value, and if Alpha $>r_{\text {table }}$ is 0.6 , then it can be said to be reliable. Based on Table 3 it can be seen that all variables meet the instrument reliability requirements and can be declared reliable. 
Table 3. Reliability Test Results

\begin{tabular}{rrrr}
\hline Variable & $\boldsymbol{C A}$ & $\begin{array}{r}\text { Requiment } \\
\text { Min } \boldsymbol{C A}\end{array}$ & Ket \\
\hline Electronic Word of Mouth $(\mathrm{X})$ & 0,860 & 0,600 & Reliabel \\
Purchasing Intention $(Y)$ & 0,908 & 0,600 & Reliabel \\
Brand Image $(\mathrm{Z})$ & 0,770 & 0,600 & Reliabel \\
\hline
\end{tabular}

\section{The Results of Linear Regression Analysis}

Table 4 shows R Square of 0.318 , which is $32 \%$ of brand image can be explained by variations of Electronic Word of Mouth while the remaining 68\% is explained by other variables.

Electronic Word of Mouth variable has $t_{\text {value }}$ of 6,766 with $t_{\text {table }}$ of 1,660 and a significant value of 0,000, which shows Electronic Word of Mouth has a significant and positive effect on purchasing intention and $t_{\text {value }}>t_{\text {table }}$ which means that Electronic Word of Mouth has a significant positive effect.

From the results of research and discussion that have been done, it can be concluded if Electronic Word of Mouth has a significant positive effect on brand image and purchasing intention. If Electronic Word of Mouth is conducted by a company, it will create a good brand image in the minds of the public, a positive Electronic Word of Mouth will also have an impact on increasing consumer purchasing intention. A good brand image has a significant positive effect on purchasing intention, which can be interpreted if the brand image of a product is good; it will increase consumer purchasing intention. From the results of the research, it can also be concluded that the Electronic Word of Mouth has a significant positive effect on purchasing intention with the brand image as its medium. If the Electronic Word of Mouth about a product is positive and done occasionally, it will create a good brand image so that the impact is increasing consumer purchasing intention.

Table 4. The Results of Linear Regression Analysis

\begin{tabular}{|c|c|c|c|c|}
\hline \multirow{2}{*}{ Variable } & \multicolumn{2}{|c|}{ Reg Coeficient } & \multirow{2}{*}{$\mathrm{t}$} & \multirow{2}{*}{ Sig } \\
\hline & $\mathrm{B}$ & Std. Error & & \\
\hline Constant & 12.830 & 2.027 & 6.331 & 0.000 \\
\hline$X$ & 0.446 & 0.066 & 6.766 & 0.000 \\
\hline R Square & & 0.318 & & \\
\hline
\end{tabular}

Electronic Word of Mouth can be used as a strategy to improve a brand image if there are many positive consumer reviews about a product as performed by Indonesia "Laneige" cosmetics products in collaboration with several digital influencers in the field of beauty, which are familiarly known as beauty influencers or beauty bloggers. Beauty Influencer or beauty blogger is asked to try and review cosmetic products "Laneige" in their social media accounts; the activity is called endorse. Endorse on beauty influencers or beauty bloggers is considered capable of convincing consumers and enhancing the brand image of "Laneige" cosmetics products. In this case, the company can influence consumers with an approach in the form of Electronic Word of Mouth to create a good brand in the minds of consumers.

Based on the discussion, the advice given to companies to pay attention to Electronic Word of Mouth is done on social media. Companies can also work with various influencers 
who are experts in the world of beauty or called beauty influencers or beauty bloggers to provide product reviews on social media, especially to beauty influencers or beauty bloggers who are judged in terms of expertise, attractiveness, and quality of promotions as well as reliable reviews so that consumers can have consideration for buying a product. The Laneige product's positive reviews through Electronic Word of Mouth will form a good brand image in the minds of consumers, thus causing high purchasing intention towards Laneige products. $\mathrm{H}_{1}$ : Electronic Word of Mouth has significant positive effects.

\section{The Results of Multiple Linear Regression Analysis}

Multiple linear regression is used to analyze the effect of Electronic Word of Mouth and interest in buying "Laneige" products. The level of confidence used in this analysis is $\alpha=$ $5 \%$. The results of the multiple regression analysis are shown in Table 5.

Table 5. The Results of Multiple Linear Regression Analysis

\begin{tabular}{|c|c|c|c|c|}
\hline \multirow[b]{2}{*}{ Variable } & \multicolumn{2}{|c|}{ Reg Coeficient } & \multirow[b]{2}{*}{$\mathrm{t}$} & \multirow[b]{2}{*}{ Sig } \\
\hline & B & $\begin{array}{l}\text { Std. } \\
\text { Eror }\end{array}$ & & \\
\hline Constant & 0.180 & 2.419 & 0.074 & 0.941 \\
\hline$X$ & 0.411 & 0.080 & 5.118 & 0.000 \\
\hline $\mathrm{Z}$ & 0.274 & 0.102 & 2.702 & 0.008 \\
\hline R Square & & 0.426 & & \\
\hline
\end{tabular}

Table 5 the coefficient of determination shown by R Square of 0.426 , which is $43 \%$ of purchasing intention can be explained by variations of Electronic Word of Mouth and brand image. In contrast, the remaining $57 \%$ is explained by other variables.

Based on Table 5, it can be seen that the Electronic Word of Mouth variable has tvalue 5.118 with table 1.660 and significant value of 0.000 . The significance value of $0,000<0.05$ and $t_{\text {value }}(5,118)>t_{\text {table }}(1,660)$ which shows that Electronic Word of Mouth has a significant and positive effect on purchasing intention.

It can be concluded that if Electronic Word of Mouth successfully affects consumers; the purchasing intention in the product will be even higher. This is indicated if cosmetics products "Laneige" do a lot of Electronic Word of Mouth on social media, then consumers will be interested and look for more information about the product. Information received by consumers can be a consideration for buying cosmetic products "Laneige". Electronic Word of Mouth is conducted in the form of reviews from beauty influencers or beauty bloggers who are honest reviews given after using the cosmetic product "Laneige". The potential consumers would have an interest in buying products and put their trust in the product because beauty influencers or beauty bloggers are considered to have experience of beauty products. Therefore, Electronic Word of Mouth is crucial because it can influence consumer purchasing intention. $\mathrm{H}_{2}$ : Electronic Word of Mouth has a significant positive effect on accepted purchasing interest.

The brand image variable has a $t_{\text {value }} 2.702$ with a $t_{\text {table }} 1.660$ and significance value of 0.008 . Significance value $0.008<0.05$ and $t_{\text {value }}(2.702)>t_{\text {table }}(1.660)$ which shows that brand image has a significant and positive influence on purchasing intention. This shows that the brand image has a significant positive effect on purchasing intention received. 
It can be interpreted that the better the brand image, the higher the consumer purchasing intention. Companies can create positive perceptions from consumers about products in the form of good quality, attractive packaging, and affordable prices. As done by "Laneige", to enhance their brand image, they offer elegant packaging on their products. "Laneige" provides travel size measurements on skincare products, making it easier for consumers when traveling. There are also sample sizes on some of his products, so consumers can consider buying a full size of "Laneige" cosmetic products to avoid dissonance after purchasing a product. "Laneige" already has a good brand image because it is understood to understand the needs of consumers by providing various sizes of its products. A good brand image on Laneige will increase consumer purchasing intention, they will feel the cosmetic product "Laneige" is worth to buy even though the price given is not cheap, but in accordance with the quality of the product.

$\mathrm{H}_{3}$ : Brand Image has a significant positive effect on Purchasing Interest received.

Intervening variable testing uses path analysis. Path analysis is used to determine the pattern of relationships between three or more of the variables. Path analysis in this study is used to determine whether the brand image can be a mediation between Electronic Word of Mouth of purchasing intention.

Based on the results of the coefficient of determination of equation I Table 4 obtained $\mathrm{R}$ square value of 0.318 , then the value is

$$
\begin{aligned}
& e_{1}=\sqrt{1-R^{2}} \\
& e_{1}=\sqrt{0.682}=0.825 .
\end{aligned}
$$

On Table 5 , the $\mathrm{R}$ square value is 0.426 , the value is

$$
\begin{aligned}
& e_{2}=\sqrt{1-R^{2}} \\
& e_{2}=\sqrt{0.574}=0.757
\end{aligned}
$$

Sobel Test is used to determine the significance of the indirect effect of Electronic Word of Mouth on purchasing intention.

$P_{1} P_{3}=(0.446) \times(0.274)=0.122204$

The total influence of Electronic Word of Mouth on Purchasing Intention is

$0.411+0.122=0.533$.

$S P_{1} P_{3}=\sqrt{P_{3}{ }^{2} S P_{1}{ }^{2}+P_{1}{ }^{2} S P_{3}{ }^{2}+S P_{1}{ }^{2} S P_{3}{ }^{2}}$.(3)

$S P_{1} P_{3}=0.04931$

We can calculate the $t$ statistic the effects of mediation with the following formula:

$$
t_{\text {value }}=\frac{P_{1} P_{3}}{S P_{1} P_{3}}
$$


Chikita Fatimasokasari Supradita1, Surpiko Hapsoro Darpito, and Dwi Hari Laksana: Brand Image as A Mediation of Electronic Word of Mouth on Purchasing Intention of Laneige

$t_{\text {value }}=2.4782$

The result of t-value is 2.478 and from the table with a significance level of 0.05 is 1.660 ; therefore, it can be known that $t_{\text {value }}>t_{\text {table }}$ is $2.478>1.660$. From these statements, it can be concluded that the medium coefficient is significant, which means there is a medium effect.

It can be seen that Electronic Word of Mouth has better effectiveness on purchasing intention if Laneige cosmetics products have a good brand image. Electronic Word of Mouth conducted by beauty influencers or beauty bloggers will be more convincing because consumers have understood and are familiar with Laneige cosmetics products. Consumers will be interested and have an interest in finding information about "Laneige" cosmetic products from various reviews given by beauty influencers or beauty bloggers. The availability of positive information obtained by consumers about a product will be a consideration for buying a product. Therefore, the more Electronic Word of Mouth will create a good brand image and increase purchasing intention in consumers.

$\mathrm{H}_{4}$ : Electronic Word of Mouth has a significant positive effect on Purchasing Intention with Brand Image as an acceptable intervening variable.

\section{CONCLUSION}

From the results of research and discussion that have been done, it can be concluded if Electronic Word of Mouth has a significant positive effect on brand image and purchasing intention. It happened if Electronic Word of Mouth conducted by a company will create a good brand image in the minds of the public, a positive Electronic Word of Mouth will also have an impact on increasing consumer purchasing intention. A good brand image has a significant positive effect on purchasing intention, which can be interpreted if the brand image of a product is good; it will increase consumer purchasing intention. From the results of the research conducted, it can also be concluded if the Electronic Word of Mouth has a significant positive effect on purchasing intention with the brand image as its medium. If the Electronic Word of Mouth has a positive impact and is done on several platforms, it will create a good brand image so that the impact is increasing consumer purchasing intention.

The results of this study can provide input to companies to pay attention to the Electronic Word of Mouth conducted on social media. Companies can also work with various influencers who are experts in the world of beauty or called beauty influencers or beauty bloggers to provide product reviews on social media, especially to beauty influencers or beauty bloggers who are judged in terms of their expertise, attractiveness, and quality of promotions as well as reliable reviews so that consumers can have consideration for buying a product. If a positive review or review of cosmetic products "Laneige" through Electronic Word of Mouth will form a good brand image in the minds of consumers, thus causing high purchasing intention in cosmetic products "Laneige".

It is expected that the results of this study can be a reference to increase knowledge in the field of marketing management. The results of this study indicate that brand image can act as a medium of the influence of Electronic Word of Mouth on purchasing intention. Future studies are suggested to add one or more other independent variables that can influence purchasing intention. The addition of independent variables can be useful to complete this 
study because it is considered that there are still other independent variables outside the research that can influence purchasing intention so that further research will provide more extensive knowledge.

\section{REFERENCES}

Assael, H (2004). Consumer Behavior and Marketing Action, Edisi 3, Cincinatti: SouthWestern College Publishing

Chang, Hsin-Hsin \& Liu, Ya-ming. (2009). The Impact of Brand Equity on Brand Preference and Purchasing Intention. Service Industries Journal, 29 (12), 1687-1706

Chartterjee, P. (2001). Online Review: Do Consumer Use Them?. Advances in Consumer Research, 28 (1)129-133.

Chevalier, J.A. \& Mayzlin, D. (2006). The Effect of Word of Mouth on Sales: Online Book Reviews. Journal of Marketing Research, 43 (3), 345-354

Hennig-Thurau, T., Gwinnwe, K.P., Walsh, G. \& Gremler, D. D. (2004). Electronic Word-ofMouth via Consumer-Opinion Platforms: What Motivates Consumer to Articulate Themselves on the Internet?. Journal of Interactive Marketing, 18 (1), 38-52.

Hu, N., Pavlou, P. A., \& Zhang, J. (2006). Can Online Reviewa Reveal a Product's True Quality?: Empirical Findings and Analytical Modeling of Online Word-of-Mouth Communication. In J. Feigenbaum, J. Chuang, \& D. M. Pennock (Eds.), Proceedings. Presented at The $7^{\text {th }}$ ACM Conference on Electronic Commerce.

Jalilvand, Mohammad Reza \& Neda Samiei. (2012). The Effect of Electronic Word of Mouth on Brand Image and Purchasing Intention: An Empirica; Study in The Automobile Industry in Iran. Marketing Intelligence \& Planning, 30 (4), 460-476.

Kotler, Philip \& Keller. (2012). Manajemen Pemasaran Edisi Ketigabelas. Jakarta: Erlangga

Kuwara, Yasue. (2014). The Korean Wave: Korean Popular Culture in a Global Context. New York: Parlave Macmillan.

Litvin, Stephen W; Ronald E. Goldsmith \& Bing Pan. (2008). Electronic Word-of-Mouth In Hospitalty and Tourism Management. Collage of Business and economics.

Marbun, B. N. (2003). Kamus Manajemen. Jakarta: Ghalia Indonesia.

Morissan, M.A. (2010). Periklanan: Komunikasi Pemasaran Terpadu Edisi 1. Jakarta: Kencana.

Reza M, Maulana \& Widowati Retno. (2018). Pengaruh Electronic Word of Mouth Terhadap Minat Beli Melalui Citra Merek dan Kepercayaan Merek Sebagai Variabel Intervening.Thesis. Yogyakarta: Universitas Muhammadiyah Yogyakarta.

Samuel, Hatane \& Lianto, Adi Suryanata. (2014). Pengaruh Analisis eWOM, Brand Image, Brand Trust, dan Minat Beli Produk Smartphone di Surabaya. Jurnal Manajemen Pemasaran, 8 (2).

Schiffman, Leon \& Kanuk, Leslie Lazar. (2008). Perilaku Konsumen. Jakarta: PT. Indeks Gramedia.

Semuel, H \& Wijaya, E. (2008). Corporate Social Responsibility, Purchasing Intention, dan Corporate Image pada Restoran di Surabaya dari Perspektif Pelanggan. Jurnal Manajemen Pemasaran, 3, 35 - 54.

Stelzer, Michael A. (2016). Social Media Marketing Report: How Marketers Are Using Social Media to Grow Their Businesses. SocialMedia Examiner

Wang, Xhuehua \& Yang, Zhilin. (2010). The Effect of Brand Credibility on Consumers Brand Purchasing Intention in Emerging Economies: The Moderating Role of Brand Awareness and Brand Image. Journal of Global Marketing, 23, 177-188 